\title{
Societal choices for sustainability - an evolutionary perspective
}

\author{
Ralf Brand \\ Manchester Architecture Research Centre, \\ School of Environment and Development, \\ The University of Manchester, \\ Humanities Bridgeford St. Building, \\ Oxford Road, \\ Manchester M13 9PL, UK \\ Fax: +44 1612756893 \\ E-mail: ralf.brand@manchester.ac.uk
}

\begin{abstract}
This article investigates the implications of an evolutionary perspective to the discourse on sustainability. For this purpose, Richard Dawkins' concept of 'memes' - a systematic analogy between the evolution of species to the evolution of ideas and artefacts - is introduced along with recent further developments, namely, by John Langrish who disaggregates memes into smaller and conceptually more manageable units: recipemes, selectemes and explanemes. This article highlights the theoretical and practical implications of these approaches for the sustainability discourse. Among the most interesting themes is the memetic derivation of the concept of coevolution between the social and the technical that has been discussed in the STS literature for a number of years. In a final section, this article presents a memetic interpretation of a strong sustainability concept and uncovers its impracticality, thus highlighting the necessity for ethical and political action.
\end{abstract}

Keywords: behavioural change; coevolution; efficiency; evolution; memes; memetics; societal choices; sufficiency; sustainability; technical fixes evolutionary perspective; Dawkins; Langrish; recipemes; selectemes; explanemes; STS; ethical and political action; sustainable society.

Reference to this paper should be made as follows: Brand, R. (2010) 'Societal choices for sustainability - an evolutionary perspective', Int. J. Sustainable Society, Vol. 2, No. 1, pp.1-16.

Biographical notes: Ralf Brand is a Lecturer at the Manchester Architecture Research Centre at the University of Manchester. His research interest is inspired by the research tradition STS (Science and Technology Studies) and focuses on the mutual shaping dynamics between all kinds of urban artefacts (road networks, buildings, street furniture, etc.) and social practices (shopping routines, perceptions of safety, commuting patterns, etc.). He employs this conceptual approach mainly to two substantive issues: urban sustainability and contested cities. He is also an experienced consultant for the participatory development and implementation of local sustainability strategies. For further information see www.ralfbrand.com.

Copyright (C) 2010 Inderscience Enterprises Ltd. 


\section{Introduction}

If we boil down the plethora of analyses and ideas within the bustling sustainability discourse, we end up with two residues that can be dissected no further: technical fixes vs. behavioural changes (Sangle, 2008; Uskokovi, 2008, p.86). I described these two approaches to sustainable development elsewhere (e.g. Brand, 2005) and demonstrated the usefulness of this redescription to conceptually grasp the prevailing sustainability discourse. The spectrum from technical fixes to heroic choices covers almost the whole breadth of the mainstream debate about sustainable development. Some perceive these two main strands as mutually exclusive (e.g. Tate and Mulugetta, 1998 or Lamberton, 2005) while others argue that sustainability is about employing both as a 'middle way' (Uskokovi, 2008, p.86): a pinch of better technologies here (i.e. more efficiency) and a dash of more moral lifestyles (i.e. sufficiency) there. This article explores what analytical and practical consequences emerge if we apply Richard Dawkings' (1976) concept of 'memes' to this discussion.

For this purpose, the meme-concept will briefly be introduced along with some further developments by Langrish (2004) who disaggregates the concept into more manageable units. Memes, according to Dawkins, are the cultural analogy to genes, the essential building blocks or defining features of man-made things. As a gene is not only able to but also 'wants' nothing else but to replicate itself, a meme too is a selfish and self-replicating unit of cultural achievements such as a song, idea, technology, slogan, logo, theory, ritual and dance, in short any kind of artefacts be it physically or mentally manifested. Whereas an organism serves as host for genes, the human mind is the host for memes. Another way to put it would be to say that human beings are the bumble bees of memes. McLuhan made an almost identical comment, although with a strong pessimistic undertone, when he wrote that 'technology has reduced us to the 'sex organs of machines" (cited in Feenberg, 1995, p.5).

Where the analogy to genetics gets especially interesting is when we apply the Darwinian notion of change to the development, improvement or deterioration of memes. This is a "neo-Darwinian view of design change [characterized by] natural selection plus memes, their competition, their modes of transfer, and their transformation; i.e. memetics" (Langrish, 2004, p.15). In genetics, it is widely acknowledged that no gene Is (note the capital 'I') inherently better than any other gene. William James (1842-1910) remarked in this context over 100 years ago that "the finch with the better-adapted beak isn't smarter or nobler than the other finches" (according to Menand, 2001, pp.145-146). $\mathrm{He}$, like many who firmly believe in evolution and natural selection, would agree, in a typically pragmatic fashion, that the beak of one type of finch might simply work better in the currently prevailing and largely contingent selection environment than the beak of another subspecies of finches. The reason could be that the finch with the long beak, for example, better manages to open fruits that happen to be available in its particular time and place than the one with a short beak. The former thus simply has a better chance of survival than the latter; it is, however, by no means closer to an imaginary culmination of teleological development towards a final state of the ultimately best finch. In other words, genetic evolution is conducting blind trial and error. Genes mutate by random variation, and the result is either retained or discarded by their environment. Their 'survival value (...) is determined by the circumstances they happen to meet and not by any absolute criterion of superiority. Therefore, evolution by natural selection has no preordained goal, purpose, or direction' (Basalla, 1988, p.135). The plants and animals we see today are the 
results of variations that have de-facto proven their fitness and continue to do so in the process of evolution. However, this does not guarantee their survival until the end of time.

This position is not uncontested: the English philosopher Herbert Spencer (1820 1903), for example, subscribed to a progressive view of evolution towards higher levels of complexity but this view certainly is not, or not any more, a mainstream position. As Langrish (2004, p.19) bluntly puts it: "Spencerian progress is nowhere to be seen, and should be consigned to the waste basket". "We can conclude at this point, then, that there is no higher magic to the phenomenon of genetic change than the simple fact that organisms whose genes make them well adapted to their environment have a higher likeliness to survive. No other magic, metaphysics, hope- or wish-driven mechanism required. This supports the above statement that the evolution of genes follows blind trial and error. Another position is known after the French naturalist and biologist JeanBaptiste Lamarck (1744-1829). The core idea of Lamarckian change is that "individuals adapt during their own lifetimes and transmit traits they acquire to their offspring. Offspring then adapt from where the parents left off, enabling evolution to advance" (Biocrawler, 2006a). This idea has triggered lively debates from which those rejecting the notion of bequeathing acquired characteristics usually emerged victorious. For the genetic part of our discussion, the question of Lamarckian change is actually irrelevant. We will, however, revisit it further below in the context of memetics.

Drawing an analogy from genetics to memetics, we can say that those artefacts ideas, words, habits, technologies, etc. - likely to be reproduced are the ones with memes that make them fit for their specific cultural environment. This observation is exactly what Menand (2001, p.xi) puts in the collective mouths of the fathers of American pragmatism, Dewey, James, Holmes Jr. and Peirce: “Ideas are not 'out there' waiting to be discovered, but are tools - like forks and knives and microchips - that people devise to cope with the world in which they find themselves". Certain memes and certain finchspecies therefore have in common that neither of them are inherently better than any other. Some memes might simply work better than other memes - either for their own replication (e.g. a computer virus) or for the purposes of those who have the power, money, influence and/or skills to ensure their replication in the form of a school book, patent, registered brand name and sermon or law. In most cases perceived usefulness is the main criterion of fitness. This provides support for the above statement that those artefacts get reproduced that fit into the currently prevailing (and largely contingent) social selection environment. But again, there is nothing teleological to either genetic or memetic evolution just as 'there is no [and there will never be] such thing as a perfect mammal, perfect kettle, perfect car or perfect tree' (Langrish, 2004, p.5).

\section{Laissez-faire vs. intervention}

If we accept this position and if we strive towards any kind of 'better' artefact, say, a better automobile, we thus have to admit a certain sense of irony. Ideological fervour for any better artefact would be ridiculous because there is no way of knowing that the improvement we have in mind is Really (note the capital R) better. Richard Rorty (1989) talks in a very similar sense about the liberal ironist who is convinced about her position but who at the same time is aware that her position might not be True in an ultimate sense. History abounds with what we consider today terrible examples of people 
steadfastly pursuing their conviction of a better world and ending in disaster. This is what Schwartz Cowan means by "today's mistakes may have been yesterday's 'rational choice" (cited in MacKenzie and Wajcman, 1985, p.261). Langrish (2004, pp.17-18) puts the same idea into a more evolutionary language: "Our ideas of improvement are themselves subject to Darwinian change", that is, they are contingent.

Is absolute relativism the inevitable corollary of this observation? This seems to be the case in the eyes of those who derive lethargy and resignation from this deliberation due to the angst that anything we do might be wrong. Others, especially from the far-end corner of (neo-)liberalism, seem to interject that this is the wrong kind of question because if we all just roll up our sleeves for the benefit of whatever suits the individual, we should end up with a cumulative effect that is automatically also best for humankind. In their eyes a laissez-faire approach and unhampered markets can unleash the de-facto beneficial deeds of Adam Smith's famous invisible hand. Economist, neuroscientist and Nobel-winner Friedrich Hayek, for example, pleads for "the party of life, the party that favours free growth and spontaneous evolution" (cited in Postrel, 1998, p.30). Among his like-minded comrades is Virginia Postrel, who shows "how and why unplanned, openended trial and error - not conformity to one central vision - is the key to human betterment" (Postrel, 2009). Raskin et al. (2002, p.9) describe the adherents of this position as "evolutionists [who] are optimistic that the dominant patterns we observe today can deliver prosperity, stability and ecological health".

Although this debate has clear political implications, it would be premature to make any political decision with long-term effects at that stage of the discussion because, again, some dispute the above relativistic position. Its critics claim that we know exactly where our memetic evolutionary journey ought to proceed, and that we do have ways of telling whether any given or conceivable idea or artefact is better than any other. Those who share this view can be classified into two main groups:

1 Members of the first might argue that certain memes are closer to or more congruent with ultimate Truths (again, note the capital T). This is what motivated Le Corbusier to proclaim his idea of progressing on the 'proper path' of architecture (according to Moore, 2001, p.13). Interestingly, the political consequence of this stance can also be anti-interventionist because the allegedly best solution will, sooner or later, prevail anyway. However, most followers of the congruence-with-Truth idea are convinced that we can and should avoid unnecessary and obvious detours and focus our energies, staff time, funding resources, etc. to walk down the pre- or even god-given path which, they claim, can be discovered by human beings. This position has come under massive attack in our post-modern, post-positivist, post-structuralist times. And the science and technology studies (STS) community, in particular SCOT (Social Construction of Technology), has made considerable contributions to overcome the naiveté of this position.

2 A second anti-relativist group employs moral imperatives to reestablish a superiority claim of some memes over others. Brulle $(2000$, p.6) is a representative of this camp because he argues that "ecological problems must be dealt with in much shorter time frames than can be anticipated for slow, gradual, or unintended social change. (...) We cannot leave this up to vague, indeterminate, undirected social change". Csikszentmihalyi (1997, p.47) supports this interventionist approach and exhorts us that "we have to take things in hand and shape the artefacts that will determine our future". From his analysis of the self-momentum of the memes of weapons and 
automobiles, he derives a call for memetic engineering or eumemics, that is, the attempt to ensure that "the memes that are going to colonize (...) the minds of our descendants are not going to be too detrimental to human survival"

(Csikszentmihalyi, 1997, p.47).

Many of them who are convinced of the superiority of one memetic destination over others - be it based on positivist, moral or practical ideas - might thus deliberately try to facilitate their reproduction through subsidies, education campaigns, purchases, investments, laws, etc. But the fact that we can never know what will come around the next corner of evolutionary context and the reality of unintended consequences - termed 'unconscious selection' by Darwin (according to Langrish, 2004, p.14) - should nourish a certain degree of humbleness. Taking into account what has been said before we can even postulate the need for a double irony: firstly, because human beings cannot know with certainty what the best memetic evolutionary destination is and secondly, because they cannot know what the best means are to really get there.

The fact that we cannot articulate the non-existing final destination of memetic evolution still leaves the idea of hope or striving intact. This brings us back to the discussion of Lamarckian change which, for Langrish $(2004$, p.8) 'could signify a process whereby change results from striving for improvement, and the further transmission of such improvement'. Whereas Langrish denies a Lamarckian nature of memetic change, an online encyclopedia community claims that memetics 'behaves in a Lamarckian manner, highlighting the irony of a great deal of effort and debate devoted to proving [the opposite]' (Biocrawler, 2006b). This position seems plausible because it simply says that artefacts and/or memes are often sequentially improved and that perceivably useful changes get reproduced. If someone finds a way to improve a web-browser in a way that most computer users find useful, it is realistic to expect that - given rational choices, access to information, moderate transaction costs - future web-browser releases will have this improvement built into their code. Human beings have always clung to the idea of bequeathing acquired memetic traits in combination with the idea of striving for improvement. And while I agree with Langrish on the double irony, as I called it before, we part, however, over the question whether it makes sense for human beings to strive nevertheless.

It is my conviction that it would be utterly inhuman not to strive. However, in order to minimise the risk of pursuing detrimental or even lethal goals with unsuitable or even fatal means both goals and means should be determined in an open, thorough and undistorted (Habermas, 1984) debate - with input from experts who can demonstrate, to the best of their knowledge, the causal mechanisms we ought to take into account. Whether or not we accept this normative call for democratic procedures in the pursuit of seeming improvement, it is clear that human beings cannot be stopped from striving. In other words, memetic evolution might be myopic but it is not blind because human beings have seemingly final or merely contingent desires, goals, aims, ambitions, dreams, beliefs, convictions, habits, routines, preferences and they will always try to intervene in the shaping of artefacts in a way to support their vision. 


\section{Two types of intervention}

To recapitulate, arguments for political intervention stem from those who have a strong opinion on what direction the memetic evolution of our society either will or should take; and most people seem to subscribe to either of these two positions. Regardless of what motivates the argument for intervention both groups share a trait and a problem: the assumption that the effects of our actions can be anticipated and the impossibility to really do so. The former is genetically hard-wired into human brains, at least for relatively linear and/or non-chaotic short-term effects. However, we are not well genetically equipped to deal with chaotic long-term effects. And although the attempt to predict the effect of increased $\mathrm{CO}_{2}$ levels in the atmosphere may appear hubristic and/or pathetic we are compelled to try. Human beings always have attempted to assess the effects of their actions ex ante and they always will seek to influence the future. Regardless of how good we are in this game of anticipation and planning two general types of possible memetic interventions appear and they resonate closely with the two basic strands within the sustainability discourse.

A first possible approach to shape the trajectory of memetic development is to influence the design of actual artefacts, to refine the ink of ball-pens, to optimise valve heads, or to improve safety features of nuclear reactors. This approach is, in its essence, about improving the recipe of how to do things. The second option to steer the future of memetic development is to influence the selection environment by introducing eco-labels on household appliances, tax breaks for hybrid cars or by subsidies for eco-farmers. The terms recipeme and selecteme, introduced by Langrish (2004), prove very useful to distinguish semantically and conceptually between these two basic subcategories of memes. In Langrish's (2004, p.17) own words, recipemes are 'transmittable ideas about how to do things - recipe ideas'. Selectemes are 'ideas about what sort of thing you want to do. They are involved in making decisions between alternatives. They [are] ... ideas about the marketplace, about fashion, and about the sorts of designs that their peers approve of' (Langrish, 2004, p.17). Selectemes also include 'ideas of desirability held by those who put up the money for the technology, as well as ideas of desirability held by those who buy the products of the technology' (Langrish, 2004, p.18).

Figure 1 is an attempt to visually represent the relationship between recipemes and selectemes. It shows the recipeme of, say a specific car model, inside a social selecteme. This depiction is inspired by Langrish (2004, p.18) who argued that "recipemes (...) have to FIT into an environment of selectemes". The two do not have the same identical shapes. There are gaps and tensions at certain points which reflect a mismatch between, say, the car's actual maximum speed and the socially desired maximum speed; or between the car's gas mileage and the socio-politically ideal gas mileage; or the car's design and the prevailing fashion for cars. Where mismatches get beyond a certain width, the car is likely to be a pretty slow seller or to be outlawed. In order to avoid this, the car manufacturer will try to optimise the car's maximum speed, its gas mileage and its design. In memetic parlance, the car manufacturer will change the car's recipemes, which is a typical task for engineers. In this as in many cases where a decision on one of these parameters affects the others the best a producer can do is to find a balance that maximises the fit with the selection environment as shown in Figure 2. In the context of sustainable development, this strategy closely resonates with the technical fix approach.

An improvement of the fit between an artefact and its selection environment can also and equally logically be achieved through strategic changes to the latter (i.e. the 
selectemes) as shown in Figure 3. This is an integral part of all kinds of product policies. Typical examples are entrepreneurs trying to educate potential customers about advantageous product features, business associations jointly lobbying for product labels, politicians who actually introduce them and who grant tax breaks for certain products. Rohracher and Ornetzeder $(2002$, p.73) illustrate a selectemic intervention in the context of sustainable development: "Many educational efforts and information strategies are targeting attitudes of users and aim at behavioural changes [such as] ... using public transport". Some would argue, and rightly so, that this approach correlates to a social fix agenda.

Figure 1 Recipemes and selectemes (see online version for colours)

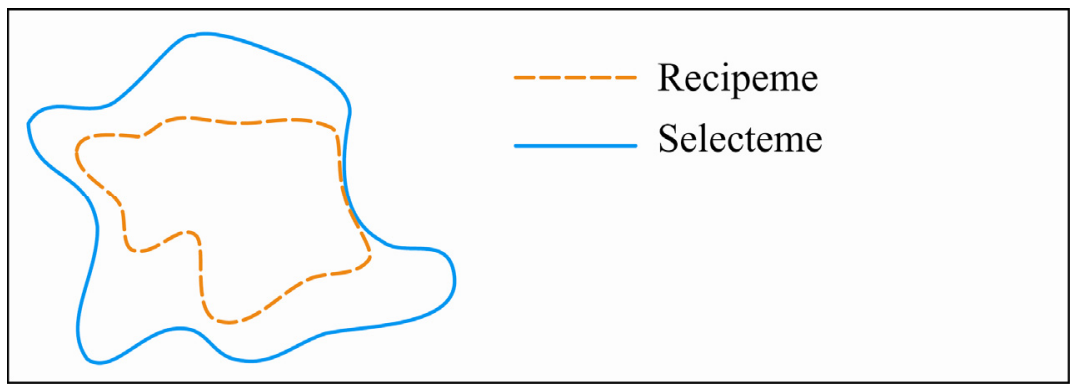

Figure 2 Changing recipemes to achieve a better fit with selectemes (see online version for colours)

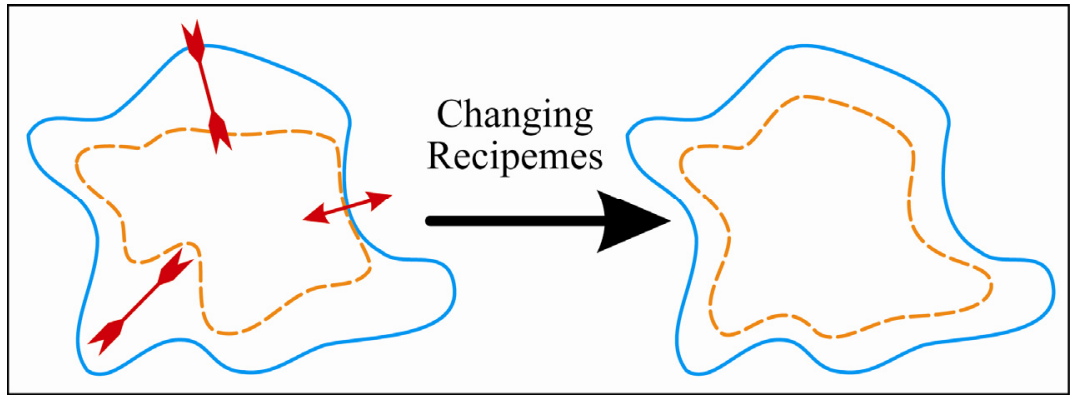

Figure 3 Changing selectemes to achieve a better fit with recipemes (see online version for colours)

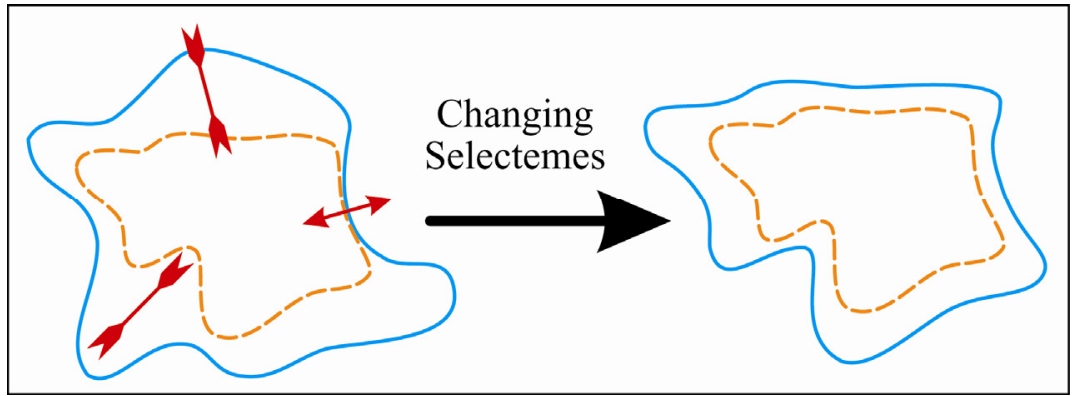




\section{Examples of oscillating memetic changes}

Regardless of which strategy is pursued, what matters is that in the end, recipemes and selectemes become more congruent. For Langrish (2004, p.17), this is a process where 'patterns of possibilities [recipemes] are compared with the patterns of need [selectemes] until there is a "click". For Maria Abu-Risha, this is a task for "purposive pattern recognition' (cited in Langrish, 2004, p.17). The following paragraphs contain some examples of the relationship between recipemes and selectemes and are intended to help digest and better understand the concept before proceeding to a third subcategory of memes.

Example 1: The history of the bicycle is a good example of how selectemes have changed, not so much through deliberate human intervention but because they have proved obsolete. Early bicycles drew much non-technical criticism, even 'condemnation from religious leaders, moralists, physicians and members of the public frightened by such an unusual machine' (McGurn, cited in Rosen, 2002, p.365). Nowadays, however, bicycles are ubiquitous and the reason for this certainly lies in part in their improved design (recipeme) but probably even more so in changed selectemes. People are not afraid any more of getting sick from riding a bicycle, sports has become an almost mandatory part of our modern lifestyle and environmental problems, traffic jams and petrol prices make many of us inclined to use the bicycle.

Example 2: The automobile has extremely successful recipemes that have 'found a medium of replication in the consciousness of humans' (Csikszentmihalyi, 1997, p.46). This has come about by linking the very idea of driving in a self-propelled machine to social status, the public belief in the auto-industry as a job creator, and especially the generation of their own indispensability through the facilitation of urban sprawl. If the social selection environment for cars changes, for example through new legislation, taste, rituals, cultural attitudes, OPEC induced price hikes for oil etc., it is quite possible that their recipemes will become relatively less successful. The potential future recipemecomplex of automobiles could be electric vehicles. But if one day they become problematic because of the scarcity of rubber for their tires and ensuing taxes on rubber the recipemes of a car will have to respond to this change of selectemes again.

Example 3: Nuclear energy fitted well in the 60s ideology of technological progress. The recipemes of nuclear power generation matched well with the prevailing socio-political selectemes, constructed around a belief in technological progress, engineering ingenuity and controllability of nature. After several nuclear accidents, culminating in the 1986 Chernobyl disaster, the social selection environment changed for nuclear energy with fears and concerns from various stakeholders, including the general public (Xia et al., 2008), which ultimately led the German government to phase this technology out over a period of two decades. However, this is not the end of history either because the memes of nuclear reactors have adapted (new safety mechanisms) or because the social selection environment has changed among some influential thinkers, including James Lovelock who has recently argued that nuclear energy is the lesser of two evils if compared to global climate change. Also the political mainstream in Finland and the UK, for example, has changed back in favour of nuclear. This story of oscillation between recipemic and selectemic change seems to support William James' "procedural model of truth where 
everything is in permanent transition toward something new, but never toward a predetermined truth" (Brand, 2005, p.74).

\section{Coevolution leads to sustainable constellations}

We can therefore conclude that the essence of memetic evolution is all about the constellation between recipemes and selectemes. If we wish to influence the memetic trajectory we thus need to focus on the tensions and distortions between recipemes and selectemes, not about either of these two - see Figure 4. Schot (1998, p.175; emphasis added) puts the same observation in this way: "Innovation (variation) and a set of context conditions (selection) together form a technological regime which guides processes of change". To ignore this simultaneous two-sided mutual shaping process would mean to watch only 'half the court during a tennis game' (Latour, 1992, p.247). This is the reason why there can never be such a thing as a sustainable recipeme; its survival and reproduction is always dependent on the social selection environment. In typical STS parlance, we can thus conclude that recipemes and selectemes coevolve anyway. A step from this description into a more prescriptive realm should thus entail the recommendation to move from repudiated to strategically harnessed coevolution and to focus on the facilitation of constellations that can be sustained. In a very literal sense, this seems to be the essence of sustain-ability. A constellation is sustainable if it has minimal distortions (i.e. small arrows) between recipemes and selectemes. A coevolution or synchronisation between technical and social change helps to minimise these distortions. Therefore, I dare claim that the concept of coevolution - in itself an artefact, an idea, a meme - is the better sustainability meme than isolated or uncoordinated efficiency (technical fix) or sufficiency (social fix) approaches.

A range of authors has undertaken the very important and useful task to prepare the conceptual path for coevolution or to explain it in more detail. Bijker and Law (1992, p.11), for example argue in a coevolutionary fashion - even though they did not use this particular term - when they assert that 'social and technical change come together, as a package'. Molina talks about "technical constituents and social constituents [and emphasizes] that in the technological process both kinds of constituents merge into each other" (Molina, 1993, cited in Hoogma et al. (2002), footnote 14, p.32). This statement clearly is inspired by coevolutionary ideas. This also applies to Schot's criticism of Basalla's (1988) and Mokyr's (1990) attempt to develop an evolutionary account of technological change. Both treat variation (the generation of new recipemes) and selection as separate processes while in Schot's (1998, p.197) view, "variation and selection are deliberately combined. Promoters of technological development create expectations in order to explore and adjust the selective environment. Thus, there are various links between variation and selection and precisely these links are important to understand the dynamics of technological development". Guy and Shove (2000, p.131) talk explicitly about "the coevolution of social and technical systems" and so do Rohracher and Ornetzeder (2002, p.74) who argue for a 'fruitful coevolution of technology design and use'. Hoogma et al. take an evolutionary stance to explain the effectiveness of Strategic Niche Management. It harnesses a

\footnotetext{
"co-evolutionary process of variation and selection, in which external selection pressures are anticipated by the innovator organization and incorporated into company $\mathrm{R} \& \mathrm{D}$ and production policies; the external selection environment in
} 
turn is shaped by the policies of the innovator vendor and a host of other actors who strive to promote (and control) a particular technology (Hoogma et al., 2002, p.19)."

Elsewhere (Brand, 2005), I also elaborate on the idea of coevolution and on the way this concept can be employed for sustainability goals. While this publication is an attempt to provide advice on how, in very concrete terms, to organise coevolutionary processes I am convinced of the need for even more practical recommendations, almost like tool kits, on this issue. While this can not be the purpose of this paper, it has at least shown that Langrish's concept of recipemes and selectemes serves as useful heuristic device to underpin the idea of coevolution from an analytical perspective. Interestingly, the final report of the UK Foresight Sustainable Energy Management and the Built Environment Project (2008) adopted the coevolution concept as one of its guiding principles.

Figure 4 Changing recipemes and selectemes to achieve a better constellation (see online version for colours)

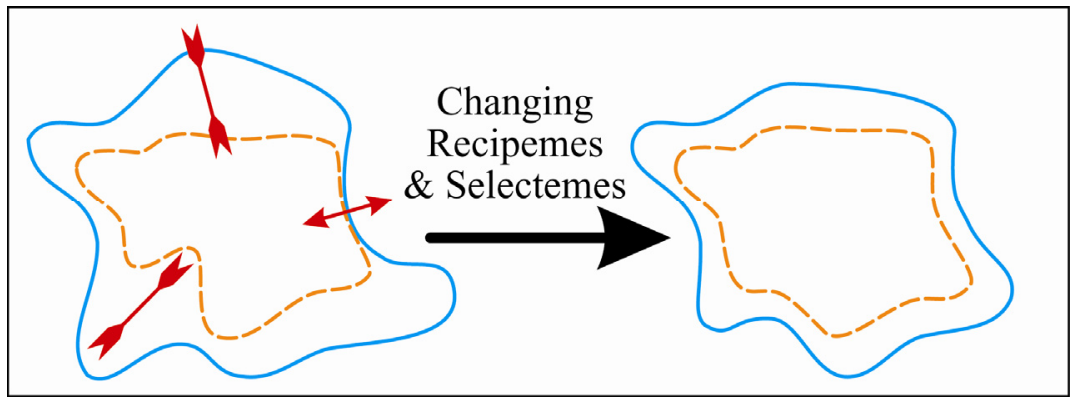

\section{Explanemes}

What has not yet been explored is the memetic interpretation of the fact that the social selection environment is itself a social product and is embedded in another selective environment. To use an earlier example: the selecteme let us subsidise nuclear energy is dependent upon other, more generic and less technology-specific ideas like riskperception, notions of the good life, ethical standards and so on. These ideas provide the explanations of why we select some artefacts for reproduction and others for the idea bin. This consideration is what makes Langrish suggest another subcategory of memes: explanemes. They are "ideas that provide the basis for answering 'why' questions" (Langrish, 2004, p.17). Basalla makes the same point when he states that "ultimately, the selection is made in accordance with the values and perceived needs of society and in harmony with its current understanding of "the good life" (1988, p.viii). Explanemes provide the standards upon which we decide which selecteme to apply when 'selectemes are in competition with other selectemes' (Langrish, 2004, p.18). They can therefore be described as meta-selection memes and are depicted as such in Figure 5. 
Figure 5 The relationship between recipemes, selectemes and explanemes (see online version for colours)

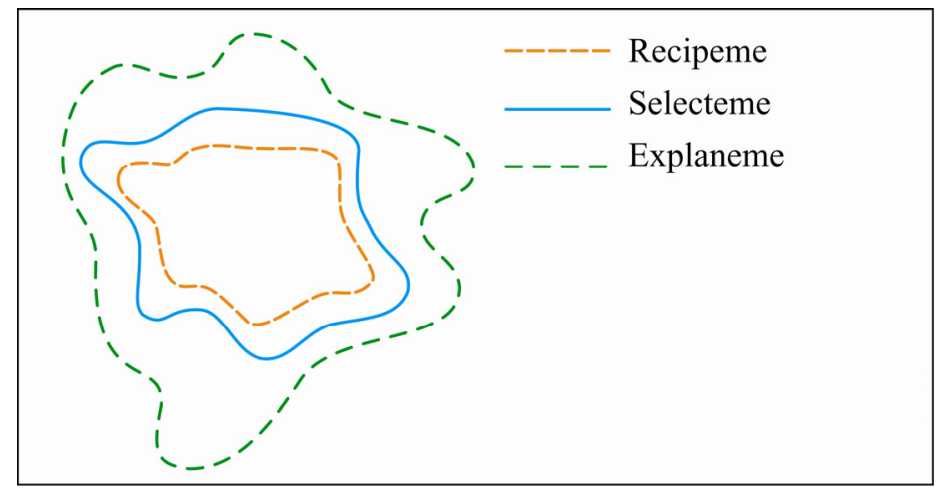

There are of course also distortions and tensions between explanemes and selectemes but the overall idea of improving their constellation still makes sense. So if we succeed in minimising tensions between recipemes and selectemes and between selectemes and explanemes, we can expect this constellation to be quite successful, to be reproducible or, in other words, to be sustainable. The idea of sustainable development proper seems to have found a conceptual representation in such a scenario. However, because social dreams, aspirations and visions are part of this system, they cannot serve as reference point by which we can judge whether or not the outcome of such a successful constellation is really good. A Green Party representative in the USA - or, for that matter, agnostics, atheists and many democrats - would argue that the following, smoothly nested meme-constellation is undesirable: allegedly divinely-inspired, narratives (explanemes) are employed to explain why the national energy security (selectemes) vindicates the development of drilling technologies (recipemes) that can be used in the Arctic wildlife refuge. It seems, then, that another version of an earlier argument comes back here with its full thrust: we have no way of knowing what kind of explaneme we should adhere to. While many of us think they know, historical hindsight tells us that the needs that inspired our visions were constantly changing. "At one time need prompted the building of pyramids and temples, at another time it inspired movement about the earth's surface in self-propelled vehicles, journeys to the moon, and the incineration and irradiation of entire cities' (Basalla, 1988, p.13-14). In other words, there seems to be no way of proving whether a development that can be sustained because of minimal intra-constellation distortions is good or needed. In other words, replicability can be a temporary and contingent fad. Is this the point where knock-out relativism cannot be fought back any longer?

A memetic interpretation of advertisement seems to support this pessimistic outlook. Advertisement has drifted away from factual information about a product to the creation of a certain attitude to life, certain life styles and the shaping of ideals, wishes, dreams, ambitions, desires, goals, beliefs and convictions. This is, in essence, an explanemic intervention. If a company wants to sell a gas-guzzler it might of course lobby against tax increases on gasoline (selectemic intervention) but it will certainly also emphasise the autonomous life the owner of the new car can life, alone and very masculine at the summit of a winding unpaved road where only a powerful machine can take him. While 
most sustainability advocates might scold this approach as an outgrowth of unethical commercial greed, they too try to influence attitudes, preferences and emotions. Awareness campaigns, for example, are a typical tool in the arsenal of environmentalists who try to sensitise people for technological risks, influence their appreciation of organic food or foster the adoption of 'sophisticated modesty' (Strong, 2001, p.5). In other words, explanemic approaches try to influence the public perception of usefulness and desirableness, they try to make things sexy.

\section{System boundaries}

The inability to define absolute explanemes still threatens to drown us in a sea of absolute relativism. Luckily, Richard Rorty offers a life-saving argument which seems to be immune against all kinds of relativistic encroachments: his litmus test is whether the outcome is pain and humiliation. Every human being, Rorty argues, perceives these phenomena in the same way, so it would be nonsense to subject them to individualistic interpretation. In a good society, then, those types of recipeme-selecteme-explaneme constellations are likely to be reproduced in the long-run that prove to be effective in the elimination of pain and humiliation. But unfortunately, there is evidence that this normative imperative is not always adhered to. After all, there have been barbaric times when an ideology of folkish supremacy (explanemes) provided the rationale for a genocide on Jews (selecteme) and thus justified the production of Cyclon-B Gas (recipeme). And for several years, this constellation has actually been terribly successful. The best or least dangerous of our options might thus be to develop explanemes with everyone's involvement. This is a call for a participatory and democratic definition of the good life and of the definition where the good life starts to collapse. Once this has been achieved, we should try to monitor our collective drift in relation to this fixed goal - no matter how arbitrary it might be as long as it has been defined in an undistorted debate. This is the idea of striving being harnessed for human and humane purposes.

If we cannot agree on a definition of the good life or if we collectively decide to pursue ultimately lethal goals there is still one final systemic border. This assumption rests with the idea that all types of memes are again nested within a larger environment as depicted in Figure 6. This fourth shell is meant to demonstrate that explanemes, too, have to prove their fitness within their environment. Although Langrish (2004, p.14) does not spell out this idea he seems to share this view at least implicitly because he states that "as a society, we can use reason to attempt to make improvements, but there always is uncertainty about outcomes so we still are left with a Darwinian natural selection system underpinning our efforts". The notion of an outer, absolute and incontestable environment rests on the premise that there is reality out there. In this question I side once more with Rorty $(1989$, p.4), who suggests that there is a 'distinction between the claim that the world is out there and the claim that truth is out there'. The criterion of fitness in this case is the avoidance of systemic collapses; be this the financial breakdown of a national pension system or the collapse of the gulf-stream. The concepts of 'environmental space' (Opschoor, 1994) or 'ecological footprint' (Wackernagel and Rees, 1999) are attempts to determine final criteria for system overshoot. According to Meadows et al. (1992) report beyond the limits we have already violated absolute ecosystemic boundaries. But despite the fact that effects described by these authors have turned millions of people into environmental refugees the world is still spinning. This is 
not tasteless cynicism but merely evidence for the fact that even the definition of systemic collapse is a matter of degree and thus subject to interpretation and power plays. Therefore we have to politicise the Lomonosov-Lavoisier law ('matter cannot be created nor destroyed') which might be correct in a hard science way but whose implication for humanity is more political than Lempert and Nguyen (2008) acknowledge.

Total collapse can only be detected with certainty in retrospect and the fate of the Easter Island and other civilisations that exceeded their environmental limits are dunning points in case. Obviously, we should no rely upon such ex-post evaluations. Not because nobody would be around any more to appreciate this knowledge but because the path towards collapse entails huge amounts of suffering for large parts of the global population. We have been at this point of the discussion already and I suspect there is no Archimedean point to which we can resort. The evolutionary and memetic discourse about sustainable development is a recursive venture. There is, then, no alternative to the tedious and messy project of permanently setting, assessing and readjusting common goals and of hammering out man-made yardsticks that can tell us whether we are drifting towards or away from them. There will not be definitive and undisputed answers but this is as good and noble as our human situation will ever get. This is, by the way, exactly what Dawkins emphasised in the same chapter in which he originally introduced, or popularised, the concept of memes:

"One unique feature of man, which may or may not have evolved memetically, is his capacity for conscious foresight (...) A simple replicator, whether gene or meme, cannot be expected to forgo short-term selfish advantage even if it would really pay it, in the long term, to do so (...) Even if we look on the dark side and assume that individual man is fundamentally selfish, our conscious foresight - our capacity to simulate the future in imagination - could save us from the worst selfish excesses of the blind replicators. We have at least the mental equipment to foster our long-term selfish interests rather than merely our short-term selfish interests. We are built as gene machines and cultured as meme machines, but we have the power to turn against our creators. We, alone on earth, can rebel against the tyranny of the selfish replicators (1976, pp.200 201)."

Figure 6 System boundaries as ultimate frame of reference for all memes (see online version for colours)

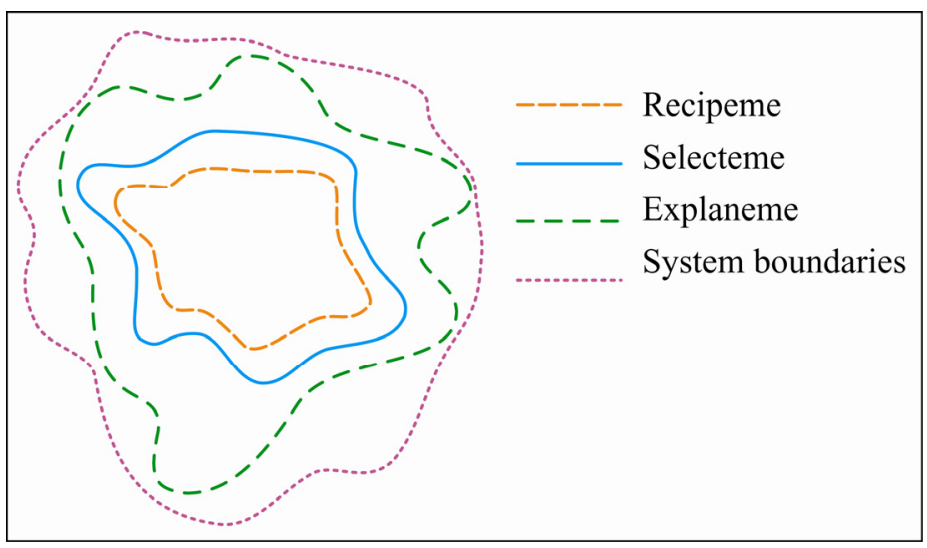


Because our long-term selfish interests is not pre-given the argument is forced to go back once again - this time, however, with more optimism - to the aforementioned challenge to collectively define the good life in an open, undistorted and inclusive debate. In memetic terms: we should focus on the development of really good explanemes at all political levels.

\section{Conclusions}

Some of the ideas presented in this paper are mere reproductions of earlier ones, others are, to the best of my knowledge, new. Among the old ones is Dawkins' concept of memes and Langrish's distinction between recipemes, selectemes and explanemes. The latter also suggested, at least implicitly, that recipemes can be understood as nested within selectemes. What I consider a genuinely new contribution to the discourse on the evolution of ideas and artefacts is the babushka model, the cascading nesting of recipemes, selectemes, explanemes and ultimately system boundaries. Probably a more speculative statement is the idea that distortions or boundary violations are more severe in terms of human suffering the closer they are to the outer shells. What I would defend more firmly, however, is the new idea on constellations between adjacent shells which can be seen as a memetic derivation of what other authors have termed coevolution.

What difference do these considerations make? They face the same challenge like all ideas: selection. How many people are likely to adopt and reproduce these ideas; and how influential are they? Are the babushka model and all the rest able to be sustained? These ideas do not represent ultimate truths but they might be perceived as useful tools to think with. In this regard I think the prevailing selectemes for sustainability-related ideas are rather receptive for the babushka model. Humankind has agreed on some, albeit vague, goals in documents like Agenda 21 (UNCED, 1992) and the search is on for the best approaches to achieve these goals. The thoughts offered in this paper could be one part of a systematic search heuristic for suitable approaches. The notions of efficiency and sufficiency as well as the working principles of coevolution, for example, are now better visible, and the advocates of coevolution seem to have new, memetic, ammunition for their cause.

\section{References}

Basalla, G. (1988) The Evolution of Technology. Cambridge: Cambridge University Press.

Bijker, W. and Law, L. (1992) 'General introduction', In W. Bijker, and J. Law (Eds). Shaping Technology/Building Society: Studies in Sociotechnical Change. Cambridge, MA: MIT Press, pp.1-14.

Biocrawler (2006a) Jean-Baptiste Lamarck. Available at: http://www.biocrawler.com/ encyclopedia/Jean-Baptiste_Lamarck. Accessed on 22nd June 2009.

Biocrawler (2006b) Meme. Available at: http://www.biocrawler.com/encyclopedia/Meme. Accessed on 22nd June 2009.

Brand, R. (2005) Synchronizing Science and Technology with Human Behaviour. London: Earthscan.

Brulle, R. (2000) Agency, Democracy, and Nature. Cambridge. MA: MIT Press.

Csikszentmihalyi, M. (1997) 'Values and socio-cultural evolution', In M. Benedikt (Ed.), VALUE, Center 10. Austin, TX: Center for American Architecture and Design, pp.41-51. 
Dawkings, R. (1976) The Selfish Gene. New York and Oxford: Oxford University Press.

Feenberg, A. (1995) 'Subversive rationalization: technology, power, and democracy', In A. Feenberg (Ed.), Technology and the Politics of Knowledge. Bloomington: Indiana University Press, pp.3-22.

Foresight Sustainable Energy Management and the Built Environment Project (2008) Final Project Report. London: The Government Office for Science. Available at: http://www.foresight.gov. uk/Energy/EnergyFinal/final_project_report.pdf, Accessed on 22nd June 2009.

Guy, S. and Shove, E. (2000) A Sociology of Energy, Buildings and the Environment: Constructing Knowledge, Designing Practice. London: Routledge.

Habermas, J. (1984) The Theory of Communicative Action: Volume 1: Reason and the Rationalization of Society, translated by Thomas McCarthy. Boston: Beacon Press.

Hoogma, R., Kemp, R., Schot, J. and Truffer, B. (2002) Experimenting for Sustainable Transport - The Approach of Strategic Niche Management. London/New York: Spon Press.

Lamberton, G. (2005) 'Sustainable sufficiency - an internally consistent version of sustainability', Sustainable Development, Vol. 13, No. 1, pp.53-68.

Langrish, J. (2004) 'Darwinian design: the memetic evolution of design ideas', Design Issues, Vol. 20, No. 4, pp.4-19.

Latour, B. (1992) 'Where is the missing masses? The sociology of a few mundane artifacts', In W. Bijker and J. Law (Eds), Shaping Technology/Building Society: Studies in Sociotechnical Change. Cambridge, MA: MIT Press, pp.225-264.

Lempert, D. and Nguyen, H.N. (2008) 'A sustainable development indicator for NGOs and international organisations', Int. J. Sustainable Society, Vol. 1, No. 1, pp.44-54.

MacKenzie, D. and Wajcman, J. (1985) The Social Shaping of Technology. Milton Keynes, UK: Open University Press.

Meadows, D., Meadows, D.L. and Randers, J. (1992) Beyond the Limits: Global Collapse or a Sustainable Future. London: Earthscan.

Menand, L. (2001) The Metaphysical Club. New York: Farrar, Straus and Giroux.

Moore, S.A. (2001) Technology and Place: Sustainable Architecture and the Blueprint farm. Austin: University of Texas Press.

Mokyr, J. (1990) The Lever of Riches - Technological Creativity and Economic Progress. New York: Oxford University Press.

Opschoor, H. (1994) 'The environmental space and sustainable resource use', In F.J. Duijnhouwer, G.J. van der Meer and H. Verbruggen (Eds), Sustainable Resource Management and Resource Use: Policy Questions and Research Needs. Rijswijk, Netherlands: Advisory Council for Research on Nature and Environment.

Postrel, V. (1998) The Future and Its Enemies: The Growing Conflict Over Creativity, Enterprise, and Progress. New York: Free Press.

Postrel, V. (2009) Synopsis of the future and its enemies. Available at: http://www.dynamist.com/ tfaie/index.html. Accessed on 22nd June 2009.

Raskin, P., Banuri, T., Gallopin, G., Gutman, P., Hammond, A., Kates, R. and Swart, R. (2002) Great Transition - The Promise and Lure of the Times Ahead. A Report of the Global Scenario Group, SEI PoleStar Series Report No. 10. Available at: http://www.tellus.org/seib/ publications/Great_Transitions.pdf. Accessed on 15th July 2005.

Rohracher, H. and Ornetzeder, M. (2002) 'Green buildings in context: improving social learning processes between users and producers', Built Environment, Vol. 28, No. 1, pp.73-84.

Rorty, R. (1989) Contingency, Irony, and Solidarity. Cambridge: Cambridge University Press.

Rosen, P. (2002) 'Up the vélorution: appropriating the bicycle and the politics of technology', In R. Eglash, J. Bleecker, J. Croissant, R. Fouché and G. di Chiro (Eds), Appropriating Technology. Minneapolis: University of Minnesota Press, pp.365-391.

Sangle, S. (2008) 'Designing Environmental Management System for promoting sustainable consumption', Int. J. Sustainable Society, Vol. 1, No. 1, pp.29-43. 
Schot, J. (1998) 'The usefulness of evolutionary models for explaining innovation. The case of the Netherlands in the nineteenth century', History and Technology, Vol. 14, No. 3, pp.173-200.

Strong, M. (2001) 'Reforming the United Nations', The Futurist, Vol. 35, No. 5, p.4.

Tate, J. and Mulugetta, J. (1998) 'Sustainability: the technocratic challenge', Town Planning Review, Vol. 69, No. 1, pp.65-86.

UNCED (United Nations Conference on Environment and Development) (1992) Agenda 21. New York: United Nations Publications. Available at: http://www.un.org/esa/dsd/agenda21/. Accessed on 22nd June 2009.

Uskokovi, V. (2008) 'Of sustainability, elephants and prefab sprouts', Int. J. Sustainable Society, Vol. 1, No. 1, pp.85-102.

Wackernagel, M. and Rees, W. (1999) Our Ecological Footprint: Reducing Human Impact on the Earth. Gabriola Island, BC: New Society Publishers.

Xia J., Wang, J., Wang, Y. and Xing, R. (2008) 'Stakeholder pressures and the global diffusion of the ISO 14001 initiative: a resource dependence perspective', Int. J. Sustainable Society, Vol. 1, No. 1, pp.4-28. 